\title{
Thermal regime of a highly regulated Italian river (Ticino River) and implications for aquatic communities
}

\author{
Francesca SALMASO,${ }^{1 *}$ Silvia QUADRONI, ${ }^{1}$ Gaetano GENTILI,${ }^{2}$ Giuseppe CROSA ${ }^{1}$ \\ ${ }^{1}$ Department of Theoretical and Applied Sciences, University of Insubria, Via JH Dunant 3, 21100 Varese; ${ }^{2}$ Graia s.r.l., Via Repubblica \\ 1, 21020 Varano Borghi (VA), Italy \\ *Corresponding author: francesca.salmaso@uninsubria.it
}

\begin{abstract}
Thermal alteration is one of the adverse effects of flow regulation sharpened in recent years due to climate changes. In this work, we characterize the thermal regime of a highly regulated river located in Northern Italy, which is the emissary of Lake Maggiore. The thermal characteristics of the study reach are influenced by the presence of two dams and by climate warming. In the 15-year monitored period (1999-2013) a significant increase of the mean annual river temperature (i.e., $+1.8^{\circ} \mathrm{C}$ ) was indeed recorded. Minimum and maximum water temperatures were detected in correspondence of low-flow periods in February and August, respectively. During August the temperature reached a maximum of $27^{\circ} \mathrm{C}$, that is a value below the upper thermal limit of tolerance for most of the aquatic taxa collected in the study area. Moreover, the local presence of seeps and the interaction with groundwater play an important ecological role by guaranteeing patches of cool water to the aquatic communities. Nevertheless, the sensitive early life stages of fish species that spawn in spring/summer may be affected by the high summer temperatures and the expected future climate warming. The wider range of temperatures preferred by alien fish species could result into a competitive disadvantage for autochthonous species. The current minimum flows established by local laws as environmental flows appeared to be able to guarantee an acceptable thermal alteration in morphologically heterogeneous reaches where river/groundwater interaction occurred, at least within the current climatic conditions.
\end{abstract}

Key words: Water temperature; thermal alteration; regulated river; environmental flow; aquatic communities.

Received: January 2016. Accepted: August 2016.

\section{INTRODUCTION}

Thermal regime is a fundamental feature of river ecology (Ward, 1985). It is influenced by a complex system of factors, e.g., i) river discharge, which determines heat load; ii) topography and streambed morphology, which mainly determine heat exchange at the streambed/water interface; and iii) atmospheric conditions and reach scale shading by riparian vegetation, which determine exchange at the air/water interface (Caissie, 2006; Webb et al., 2008). These drivers of the river temperature are the result of both natural and anthropogenic dynamics (Poole and Berman, 2001). Among the latter, the regulation of flow regime following water abstraction and dam construction often implies direct and indirect thermal regime alteration. Depending on the dam structure, the water released in the downstream watercourse can come from the epilimnetic or the hypolimnetic reservoir layers, and thus can be warmer or colder, respectively, when compared to the river reach upstream of the reservoir (Olden and Naiman, 2010). Particularly, in mountainous areas, releases from the hypolimnion of high-elevation reservoirs can produce sharp heating or cooling of the receiving waterbody. The river water is usually warmed up by the peaking inflow during winter (i.e., warm thermopeaking) while being cooled down in summer (i.e., cold thermopeaking) (Zolezzi et al., 2011). Moreover, downstream water temperature depends on the water volume released through the dam (Poole and Berman, 2001). In low-flow conditions, reduced thermal capacity causes an increase in summer maxima and a decrease in winter minima, and widens the daily range of variability (Ward, 1985). In many rivers, summer temperature is also expected to be exacerbated in the future as a consequence of the climate changes due to both air temperature increase and a decrease of low-flow values (Mantua et al., 2010; Isaak et al., 2012; Schneider et al., 2013; van Vliet et al., 2013).

The resulting patterns of spatial and temporal variation in the water temperature downstream of a dam contribute to shape aquatic communities. Indeed, dam-induced thermal alteration can cause adverse effects on growth and distribution of aquatic organisms and on ecosystem productivity (Bunn and Arthingthon, 2002; Hari et al., 2006; Haxton and Findlay, 2008; Naiman et al., 2008; Carolli et al., 2012; Bruno et al., 2013). Intra-community interactions can be influenced as well, since species adapted to specific temperature patterns may be affected by a competitive disadvantage (Ward, 1985). 
Although thermal regime and flow regulation are strictly related and the variability of the thermal regime has a strong importance for freshwater ecosystem integrity, clear indications on how to deal with thermal regime restoration are lacking. On the contrary, the need to protect and restore natural flow variability has been widely recognized and environmental flows (e-flows) have been developed as management tools. The need to incorporate water temperature to improve the science of e-flows has recently been highlighted by several Authors (Olden and Naiman, 2010; Poff et al., 2010; Poff and Zimmerman, 2010). However, to date, only few attempts have been made to relate flow regulation to river temperature in order to define management practices able to protect both aspects of fluvial environment (Olden and Naiman, 2010). For the definition of adequate remediation actions, the effects of river discharge alteration on water temperature should be detected at different temporal (Hari et al., 2006; Toffolon et al., 2010; Zolezzi et al., 2011; Vanzo et al., 2016) and spatial scales (Brown and Hannah, 2008; Gerecht et al., 2011; Casas-Mulet et al., 2015). Recent studies (Toffolon et al., 2010; Zolezzi et al., 2011; Carolli et al., 2012; Bruno et al., 2013; Vanzo et al., 2016) focused on the identification of the relationships between hydropeaking and thermopeaking, and their ecological effects, mainly on short and medium timescales and in a mountainous context.

In this work, we characterize the thermal regime of the Lake Maggiore emissary (i.e., the Ticino River), one of the major regulated Italian rivers. Flow management in the Ticino River is mainly operated through the Miorina Dam, which was built in 1942 at the Lake Maggiore outlet and releases epilimnetic water into the downstream river. In the Ticino reach downstream of the Miorina Dam the river flow is further managed for hydro-power energy production and land irrigation, resulting in a strong flow depletion, especially during the coldest and warmest months of the year.

The thermal regime of the Ticino River is then discussed in relation to the river hydrology and streambed morphology, with a focus on the summer period, for which major effects of the thermal modification on aquatic communities are expected, because of both water abstraction and climate warming. The specific objectives of the work are: i) to describe the annual and daily cycles in the Ticino River temperature and their fluctuations in response to river discharge; ii) to investigate longitudinal variations in water temperature related to flow regulation; iii) to describe transversal variations in water temperature in response to streambed morphology; iv) to highlight possible aquatic community modifications associated with the thermal regime alteration.

The present work may address future management decisions regarding an adequate definition of the e-flows in the study context.

\section{METHODS}

\section{Study area}

The Ticino River flows from the Swiss Alps to Lake Maggiore for $\sim 90 \mathrm{~km}$ and then from the lake to the Po River for $\sim 110 \mathrm{~km}$ (Fig. 1). It is the first tributary of the Po River for flow rate (mean annual natural discharge at mouth: $348 \mathrm{~m}^{3} \mathrm{~s}^{-1}$ ). It has an $8,172 \mathrm{~km}^{2}$ watershed, including mountainous areas from the source to the lake outlet and lowland agricultural areas. Urbanized areas are mainly located near the lake and on the east bank of the lowland course.

In the present study, a $30-\mathrm{km}$ river reach downstream of Lake Maggiore was investigated (Fig. 1). The lake outflow is regulated through the Miorina Dam (Fig. 1) to optimize the water use in the downstream river and for flood control; no water diversion takes place at this dam. Water releases mainly depend on the limits established by the current laws on the water level of the lake. Discharge is controlled through movable gates, which release water from the lake surface. As calculated on a 60-year period, the average flow at the Miorina Dam is $284 \mathrm{~m}^{3} \mathrm{~s}^{-1}$. Water diversion is mostly carried out $7 \mathrm{~km}$ downstream of the Miorina Dam, at the Panperduto Dam (Fig. 1), where approximately $60 \%$ of the mean annual discharge (i.e., $170 \mathrm{~m}^{3} \mathrm{~s}^{-1}$ ) is diverted for agriculture and hydro-power energy production. Mandatory monthly-modulated minimum flows (MFs) are currently released below the Panperduto Dam and range between $4 \%$ (i.e., $12 \mathrm{~m}^{3} \mathrm{~s}^{-1}$ ) and $8 \%\left(\right.$ i.e., $22 \mathrm{~m}^{3} \mathrm{~s}^{-1}$ ) of mean annual natural flow. However, the streamflow downstream of the Panperduto Dam generally exceeds MFs during the periods of high water availability (i.e., mainly in spring due to snowmelt and in autumn due to rainfall).

Except for the presence of water diversion structures and minor riprap areas, the riverbed morphology in the study area is mainly natural, with riffles, runs and pools, and the substrate mainly composed of cobbles.

All of the data reported in the present study were collected immediately downstream of the Miorina Dam and at two sites (S1 and S2), located 3 and $23 \mathrm{~km}$ downstream of the Panperduto Dam, respectively (Fig. 1). S1 was chosen to represent the characteristics of the river reach immediately below the large diversion occurring at the Panperduto Dam. Instead S2 was located in a river section where the discharge can be higher than at S1 mainly due to groundwater contribution (at S2, in fact, the residual watershed contribution is negligible since the basin area increase between $\mathrm{S} 1$ and S2 is only $52 \mathrm{~km}^{2}$ ).

\section{Data collection and analysis}

Data on mean daily flow released through the Miorina and Panperduto dams (from 2001 to 2013) and at S2 (from 2010 to 2013) and data on mean daily water temperature 
immediately downstream of the Miorina Dam (from 1999 to 2013) were provided by the Ticino Consortium. Streamflow at S1 was considered equal to the flow released through the Panperduto Dam because of their proximity.

Flow data were used to characterize the typical annual pattern and to detect possible differences between the three sampling sites. A t-test was performed to detect possible differences among mean monthly flows between the Miorina and Panperduto dams during the period from 2001 to 2013.

Temperature data were used to characterize the thermal regime at the lake outlet during a 15-year period. For this purpose, the following six thermal metrics were calculated based on the daily values of water temperature, according to Olden and Naiman (2010): i) average timing of minimum and maximum water temperature; ii) average frequency and iii) average duration of low and high temperature events; iv) average monthly magnitude and average magnitude of 1-, 7- and 30-day minimum and maximum temperatures; v) variability, calculated as coefficient of variation (CV); and vi) predictability, calculated according to Colwell (1974) and ranging from 0 (i.e., unpredictable phenomena) to 1 (i.e., totally predictable phenomena).

A linear regression analysis on the mean annual temperature from 1999 to 2013 was performed to verify if significant warming occurred. A linear regression analysis on the mean monthly temperature as a function of the year was carried out for each month as well. Additional water tem- perature data were collected using different approaches to detect both spatial (i.e., longitudinal, lateral and depth variation) and temporal variation in the study reach.

Water temperature was measured once a month from 2010 to 2012 with a YS-I professional plus portable probe at S1 and S2 to detect the longitudinal temperature variation within the study reach. Single measurements were carried out in the central part of the main channel, i.e. in a point representative of the river section, between 10 and 12 a.m.; within this time interval, temperature values are generally intermediate between the daily maximum and minimum (Smith, 1981; Lowney, 2000), thus not representing extremes. One-way analysis of variance (ANOVA), followed by Tukey's multiple comparison test, was performed to detect possible differences among $\mathrm{S} 1$, S2, and the Miorina Dam (for the latter, the temperature values recorded on the same monitoring dates as $\mathrm{S} 1$ and S2 were used for the comparison).

Data on water temperature and on the morphological characteristics of riverbed were collected along two transects at S2 on August $5^{\text {th }}, 2013$, to detect the lateral temperature variation associated with the channel morphology. For each transect, the measurements were carried out at a 1-m interval near the riverbanks and at a 5-m interval in the central part of the channel. A total of 22 and 37 measurements were collected for the first and the second transect, respectively. At each measurement point the following data were collected: i) water temperature at the surface and at 2/3 depth (to detect the vertical

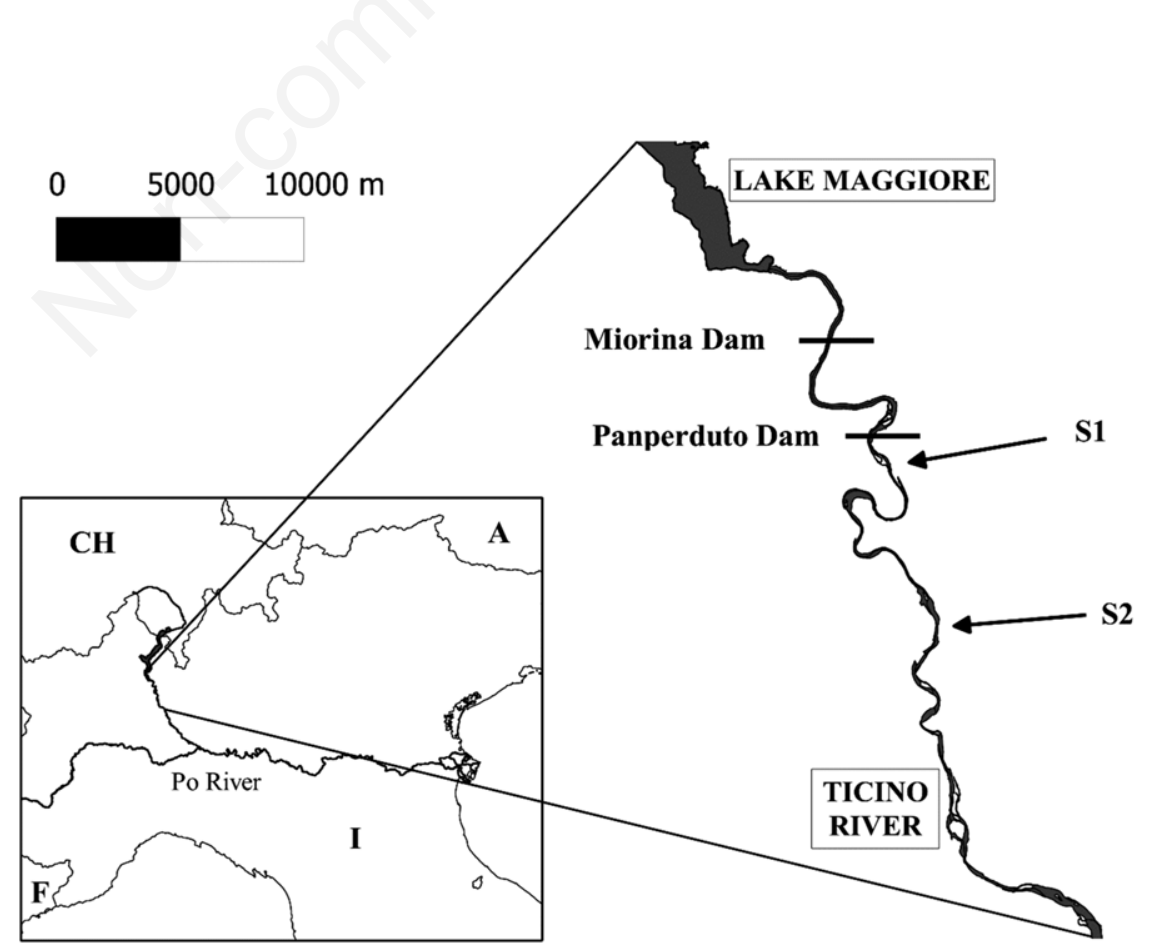

Fig. 1. Study area. Position of the Ticino River in Northern Italy (left). Detail of the investigated river stretch (right) with the Miorina and Panperduto dams and the monitoring sites S1 and S2. 
temperature variation) with a YS-I professional plus portable probe; ii) distance from the left riverbank; and iii) water depth. For each transect, air temperature and channel width were also measured. All of the measurements were carried out between 10 and 12 a.m.

A water temperature logger (Escort I-Log Temperature 62D32), recording at 10-minute intervals, was positioned at S2 from August $5^{\text {th }}$ to September 12 ${ }^{\text {th }}, 2013$, to detect the temporal (within-day and between-days) variation in the period of the year expected to be characterized by the highest water temperatures and lowest streamflows. A possible association between water temperature and flow variation was investigated by graphical comparison of daily streamflow values with temperature data measured with the data logger.

Available data on fish, benthic macroinvertebrates, macrophytes and benthic diatoms (data listed in Supplementary Tab. 1 and collected within the project Minimum flow trial in the lowland Ticino River, published on www.ticinoconsorzio.it) were used to evaluate possible effects of the summer water temperatures on local aquatic communities. These data were collected during the study period at S1 and S2 according to methods (Ministerial Decree no. 260/2010 - Criteri tecnici per la classificazione dello stato dei corpi idrici superficiali-Modifica norme tecniche D. gs. 152/2006) developed in accomplishment of the Water Framework Directive (WFD). Abundances and structural metrics (i.e., number of taxa and ShannonWiener index) were calculated for each ecological group whenever possible. Differences in the metrics values between $\mathrm{S} 1$ and $\mathrm{S} 2$ and between the summer period and the other seasons were evaluated using $t$-test.

All of the statistical analysis were performed using XLSTAT2011 software.

\section{RESULTS}

\section{Flow regime characterization}

A common annual flow pattern among the sections immediately downstream of the Miorina Dam and the Panperduto Dam was recorded (Fig. 2a). Mean monthly flows were characterized by two peaks, one in May and one in November. The first peak was 1.5 times higher than the second one. Two low-flow periods were identified: one between summer and early autumn and one in winter. During the latter, flows
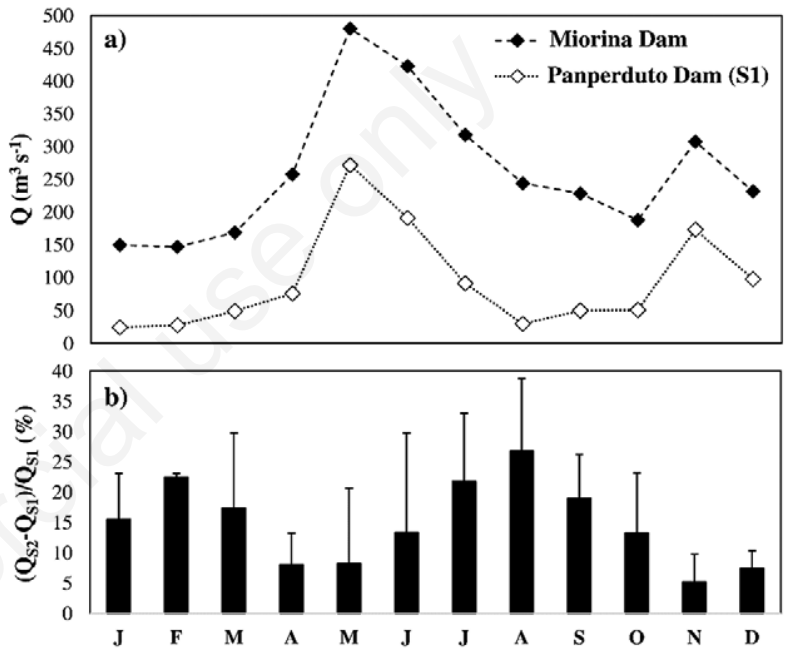

Fig. 2. a) Average monthly flow (Q) values downstream of the Miorina and Panperduto dams (monthly means for the period 2001-2013) and b) average monthly flow (Q) increase (+ standard deviation) between S1 (Panperduto Dam) and S2 (monthly means for the period 2010-2013).

Tab. 1. Mean, minimum and maximum values ( \pm standard deviation) of the average monthly temperature $(\mathrm{T})$ recorded at the Miorina Dam from 1999 to 2013. Years of minimum and maximum are also reported.

\begin{tabular}{lccccc} 
Month & Mean T \pm SD & Min T \pm SD & Year of min & Year of max \\
& $\left({ }^{\circ} \mathrm{C}\right)$ & $\left({ }^{\circ} \mathrm{C}\right)$ & & $\left({ }^{\circ} \mathrm{C}\right)$ \\
\hline J & $6.6 \pm 0.9$ & $5.0 \pm 0.2$ & 2002 & $8.5 \pm 0.5$ & 2007 \\
\hline F & $6.1 \pm 0.9$ & $5.0 \pm 0.0$ & 2005 & $8.0 \pm 0.0$ & 2007 \\
\hline M & $7.2 \pm 1.1$ & $5.8 \pm 0.8$ & 2004 & $8.8 \pm 0.4$ & 2007 \\
\hline A & $9.6 \pm 1.7$ & $8.3 \pm 1.1$ & 2003 & $11.6 \pm 2.3$ & 2007 \\
\hline M & $13.9 \pm 2.6$ & $10.8 \pm 1.6$ & 2004 & $18.1 \pm 1.2$ & 2007 \\
\hline J & $17.9 \pm 2.3$ & $15.0 \pm 0.8$ & 2001 & $19.9 \pm 1.2$ & 2011 \\
\hline J & $21.4 \pm 2.0$ & $17.8 \pm 0.9$ & 2001 & $24.0 \pm 1.8$ & 2006 \\
\hline A & $22.3 \pm 1.6$ & $20.0 \pm 0.8$ & 2002 & $24.3 \pm 1.2$ & 2012 \\
\hline S & $20.3 \pm 1.9$ & $17.7 \pm 1.6$ & 2001 & $18.2 \pm 1.1$ & 2011 \\
\hline O & $16.2 \pm 2.1$ & $13.2 \pm 2.7$ & 2000 & $14.0 \pm 1.8$ & 2006 \\
\hline N & $12.2 \pm 1.7$ & $10.2 \pm 0.6$ & 2000 & $10.7 \pm 1.2$ & 2005 \\
\hline D & $8.7 \pm 1.3$ & $7.5 \pm 1.2$ & 2001 & 2006
\end{tabular}


were more stable than in the summer period: downstream of the Panperduto Dam, days with streamflow equal to MF were on average $81 \%$ of the total number of days from January to March, while $67 \%$ from August to October. The ratio between maximum and minimum values of average monthly flows was higher for the Panperduto Dam (i.e., average flow in May / average flow in February=21) than for the Miorina Dam (i.e., average flow in May / average flow in February=3). The average monthly flow values were always significantly $(\mathrm{P}<0.01)$ lower at the Panperduto Dam than at the Miorina Dam. The percentage flow difference between the two stations was higher during the low-flow periods, with a maximum in August (i.e., the percentage difference of the mean monthly flows was $88 \%$ ).

The flow variation between $\mathrm{S} 1$ and $\mathrm{S} 2$ (i.e., the groundwater contribution) is shown in Fig. 2b. At S2, the average monthly flow values were always higher than at $\mathrm{S} 1$, with the minimum differences during the high-flow months. The maximum flow increase between the two sites was observed in August (i.e., a mean value of 23.5\%, corresponding to $9 \mathrm{~m}^{3} \mathrm{~s}^{-1}$ ).

\section{Thermal regime characterization at the lake outlet}

The lowest and highest values of mean, minima, and maxima of average monthly temperature were recorded in February and August, respectively (Tab. 1). On average, February $19^{\text {th }}$ and August $13^{\text {th }}$ corresponded to the date of minimum and maximum daily temperature, respectively (Fig. 3a).

All the minimum values of average monthly temperature were recorded before or in 2005, whereas the maximum values after or in 2005 (Tab. 1). A significant increase in the average annual temperature was observed during the period 1999-2013 (i.e., $+1.8^{\circ} \mathrm{C} ; \mathrm{R}^{2}=0.38, \mathrm{P}=0.014$; see Supplementary Fig. 1). When each month was individually analysed considering the same time interval, a significant temperature increase was recorded only for the months from August to January (i.e., the lowest regression value $\mathrm{R}^{2}=0.33$ with $\mathrm{P}=0.025$ - was detected in September, and the highest recording - $\mathrm{R}^{2}=0.43$ with $\mathrm{P}=0.008$ - was detected in November; see Supplementary Fig. 1).

Low temperature events were less frequent on average and lasted more than high temperature events (Fig. 3 b,c). The magnitudes of 1-, 7- and 30-day minimum temperatures were similar (i.e., mean values from 5.6 to $6^{\circ} \mathrm{C}$, Fig. 3d). The magnitude of 30-day maximum temperature was lower of $1^{\circ} \mathrm{C}$ than that of 1-day maximum temperature (i.e., mean values from 23 to $24.1^{\circ} \mathrm{C}$, Fig. $3 \mathrm{~d}$ ). Predictability and annual variability in water temperature were 0.52 and 0.44 , respectively (Fig. 3e).

\section{Four-dimensional thermal variation in the study reach}

The annual pattern of variation recorded at the Mior- ina Dam was similar $(\mathrm{P}>0.01)$ to those recorded at the two downstream monitoring sites (i.e., longitudinal variation, Fig. 4). For each site, the highest mean monthly temperature value $\left(\sim 23^{\circ} \mathrm{C}\right)$ was recorded in August.

The two transects measured at S2 in MF conditions on August $5^{\text {th }}, 2013$, showed a substantial lateral variation in surface temperature only in correspondence with the banks and in the case of the contact with a groundwater seep (Fig. 5 a,b). In both cases a temperature decrease from the channel centre towards the banks/seep was observed (Fig. 5 a,b). The difference in temperature values between the river course and the seep was up to $8.8^{\circ} \mathrm{C}$ (from 24.4 to $15.6^{\circ} \mathrm{C}$, Fig. 5b). The highest temperatures (i.e., up to $27.1^{\circ} \mathrm{C}$ ) were recorded in a 3-m wide stretch near a gravel bar, with a water column depth lower than
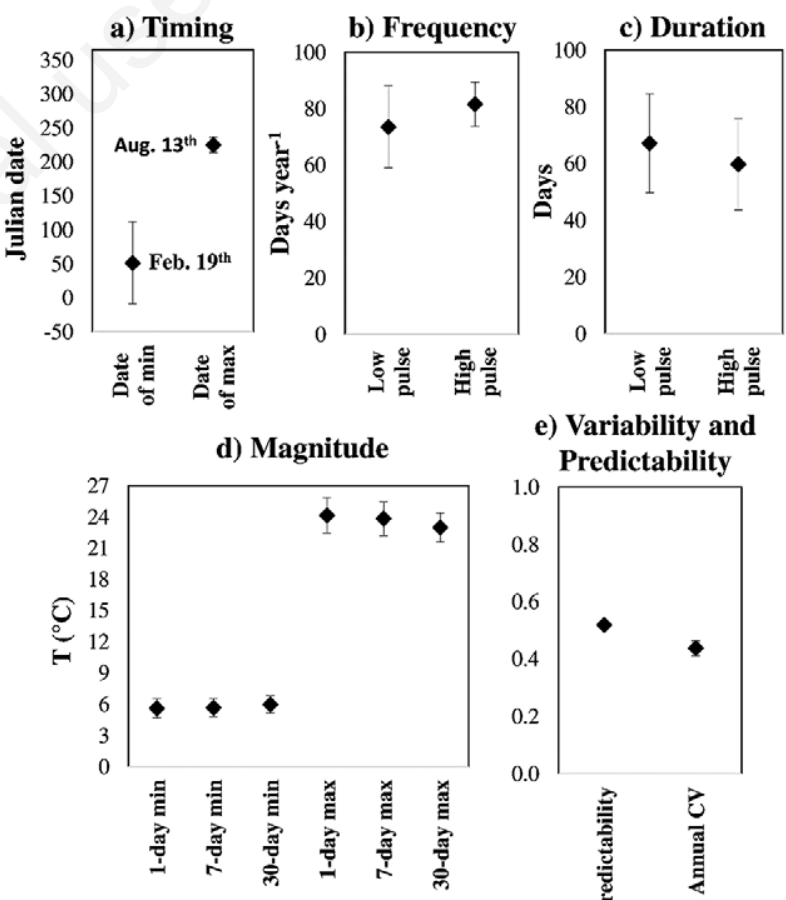

e) Variability and Predictability

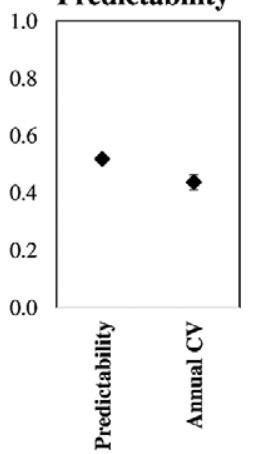

Fig. 3. Thermal regime at the Miorina Dam characterized using different thermal metrics: a) timing, b) frequency, c) duration and d) magnitude of thermal events, and e) variability and predictability of annual temperatures, according to Olden and Naiman (2010). 1-day, 7-day and 30-day minima and maxima are defined as the $\mathrm{min} / \mathrm{max}$ values of moving average calculated on 1, 7 and 30 values, respectively. Low and high pulses are defined as mean daily temperatures below the $25^{\text {th }}$ percentile and above the $75^{\text {th }}$ percentile of the annual records, respectively. Bars represent \pm standard deviation. $\mathrm{CV}$ refers to the coefficient of variation. Mean daily temperature data from 1999 to 2013 were used for the characterization. 
$20 \mathrm{~cm}$ (Fig. 5a). Except for these local variations, water temperature in most of the points along the transects was similar to that at the Miorina Dam (i.e., $\sim 24^{\circ} \mathrm{C}$ ).

A difference between the temperature values measured at the surface and at $2 / 3$ depth was recorded only in correspondence with the pool of the first transect (represented in Fig. 5a) and was $0.5^{\circ} \mathrm{C}$ (i.e., vertical variation).

The temporal daily pattern of the surface temperature recorded from August $5^{\text {th }}$ to September $12^{\text {th }}, 2013$ with the data logger deployed in the above-mentioned pool, is reported in Fig. 6 (i.e., temporal variation). During this time interval, mean and maximum temperatures were 21.6 and $25.4^{\circ} \mathrm{C}$, respectively. The daily range of variation was on average $2.1^{\circ} \mathrm{C}$, with minimum and maximum values of 1.2 and $4.0^{\circ} \mathrm{C}$, respectively. During the study period, the streamflow was generally near the MF. On August $9^{\text {th }}$, a temperature increase was observed in correspondence of a fast increase in streamflow, due to abundant rainfall and consequent water release from the Miorina Dam (Fig. 6). Recorded temperature values increased from 21.2 (corresponding to the minimum of the period $\left.5^{\text {th }}-8^{\text {th }}\right)$ to $25.4^{\circ} \mathrm{C}$ (corresponding to the maximum of the entire monitored period) within $5 \mathrm{~h}$ between August $8^{\text {th }}$ and $9^{\text {th }}$. Mean daily temperature increased from 22.1 (August $8^{\text {th }}$ ) to $24.5^{\circ} \mathrm{C}$ (August $9^{\text {th }}$ ). After the high-flow period (which lasted from August $9^{\text {th }}$ to August $14^{\text {th }}$ ), the mean daily temperature decreased to values below $21.8^{\circ} \mathrm{C}$. The streamflow from August $9^{\text {th }}$ to August $14^{\text {th }}$ was up to $\sim 16$ times the MF values $\left(\sim 20 \mathrm{~m}^{3} \mathrm{~s}^{-1}\right)$ (Fig. 6).

\section{Aquatic communities characterization}

The diatom communities were similar between the two study sites (i.e., S1 and S2). Most common species belong to genera Achnanthidium, Cocconeis, Cymbella, Fragilaria, Reimeria, Nitzschia, and Navicula; Achnanthidium minutissimum (Kützing) Czarnecki and $\mathrm{Coc}$ - coneis placentula Ehrenberg dominate the communities (Supplementary Tab. 1). Both richness (i.e., total number of species) and diversity (calculated with the ShannonWiener index) did not statistically $(\mathrm{P}>0.05)$ differ between $\mathrm{S} 1$ and S2 (Tab. 2). Total number of species ranged between 19 and 44, and diversity between 1.51 and 3.95. At both sites, the mean summer richness and diversity were not significantly $(\mathrm{P}>0.05)$ higher than the mean values recorded for the other seasons (Tab. 2).

The macrophyte communities were similar between the two study sites as well. In all of the samples the community was dominated by filamentous algae, generally belonging to the generalist taxon Cladophora, while phanerogams were rare (Supplementary Tab. 1). Total number of species ranged between 17 and 27, and percentage cover of the wetted area between $90 \%$ and $<5 \%$. Both richness and cover were not statistically $(\mathrm{P}>0.05)$ different between the two study sites (Tab. 2).

Richness and total density of the macroinvertebrate communities were not statistically ( $\mathrm{P}>0.05$ ) different between S1 and S2 (Tab. 2), and varied among 13 and 35 families, and 186 and 18,634 individuals $\mathrm{m}^{-2}$, respectively. Most abundant families were the Trichoptera Hydropsychidae, the Ephemeroptera Baetidae and the Diptera Chironomidae at both sites (Supplementary Tab. 1). Diversity was significantly $(\mathrm{P}<0.05)$ higher at $\mathrm{S} 2$ than at $\mathrm{S} 1$, both taking into account all of the collected data and summer samples and other seasons samples separately (Tab. 2), due to the lower abundance of Chironomidae.

At both sites, the fish communities were dominated by small gregarious species, like freshwater blenny (Salaria fluviatilis), Italian minnow (Phoxinus lumaireul), Italian spined loach (Cobitis bilineata), and Italian riffle dace (Telestes muticellus) (Supplementary Tab. 1). Many exotic species were present (Tab. 2 and Supplementary Tab. 1), even with high abundances (e.g., roach - Rutilus rutilus and bitterling - Rhodeus amarus). The strongly invasive Euro-

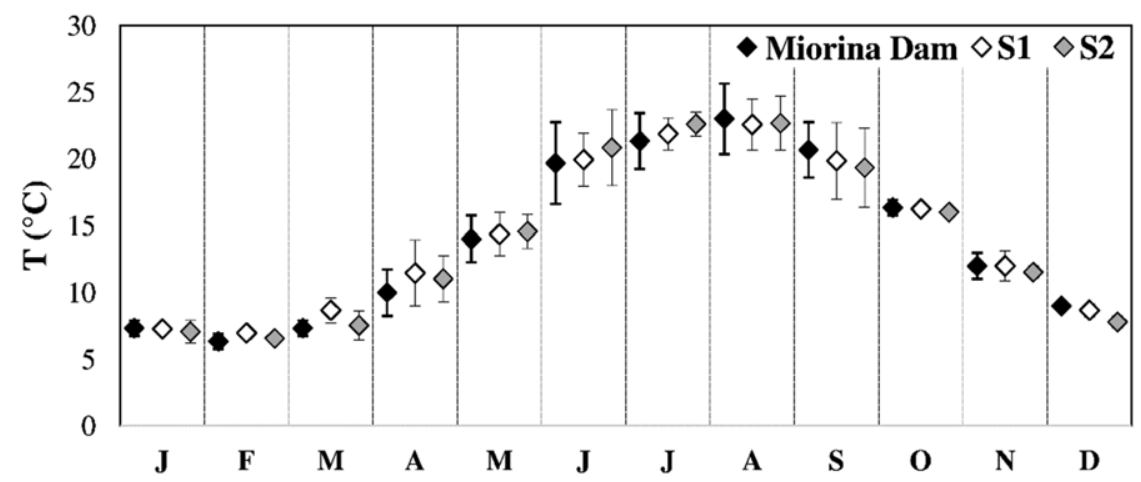

Fig. 4. Thermographs (average monthly temperature - T - values for the period 2010-2013) for the Miorina Dam, S1 and S2. Bars represent \pm standard deviation. 
pean catfish (Silurus glanis) was also present (Supplementary Tab. 1). Five species were found only at S2 (Asian weather loach - Misgurnus anguillicaudatus, Italian golden loach - Sabanejewia larvata, pike - Esox lucius, pseudorasbora - Pseudorasbora parva and European catfish), while only one species was present at S1 but absent at S2 (Italian roach - Rutilus pigus) (Supplementary Tab. 1).

\section{DISCUSSION}

\section{Thermal regime and flow regulation}

During the 15-year monitored period (1999-2013), the daily temperature of the Ticino River downstream of the Miorina Dam ranged from 5 to $27^{\circ} \mathrm{C}$, with differences of the mean annual values showing a moderate increase over time (of approximately $2^{\circ} \mathrm{C}$ ). This increase is in accordance with that reported by Ambrosetti et al. (2006) for the surface water of Lake Maggiore over three previous decades (1962-1997). An increase in the mean annual water temperature over the last century was also recorded in other European streams and large rivers, which was partly attributed to climate warming (Dokulil, 2013; Orr et al., 2015). Moreover, a further increase in the mean annual water temperature of more than $2{ }^{\circ} \mathrm{C}$ is expected in European watercourses for the $21^{\text {th }}$ century, as calculated by van Vliet et al. (2013).

Low flows downstream of the Miorina Dam were mainly recorded during winter and summer and this seasonal pattern was further sharpened in the other two downstream sections (i.e., $\mathrm{S} 1$ and $\mathrm{S} 2$ ) as a consequence of water withdrawal both for hydro-power and agricul-

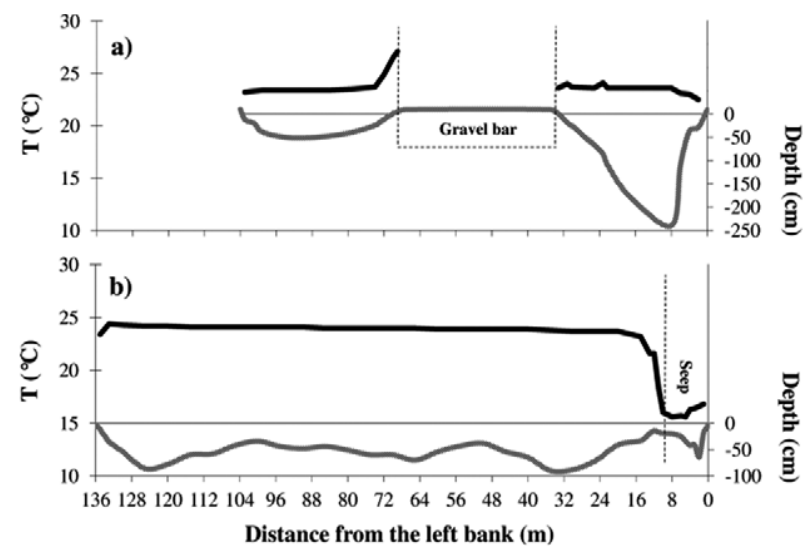

Fig. 5. Hydro-morphological and thermal transects carried out in the two sections at S2, characterized by the presence of a) a gravel bar and b) a seep. The black bold line represents the surface water temperature $(\mathrm{T})$; the grey line represents the crosssectional profile; the straight line represents the water surface.

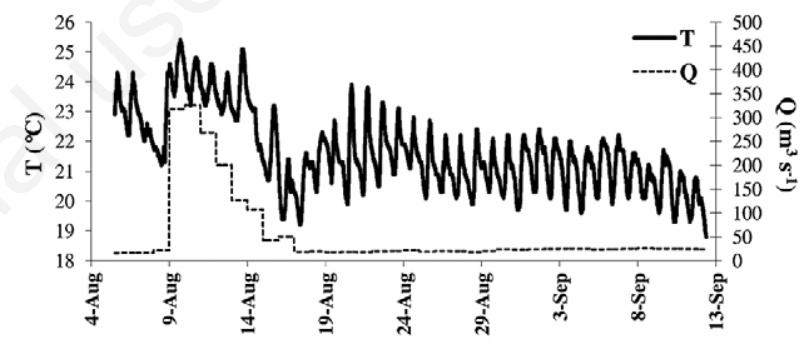

Fig. 6. Average daily streamflow (Q) and temperature (T) daily pattern recorded at $\mathrm{S} 2$ (at the left side of the pool of the transect 1, Fig. 5a) from August $5^{\text {th }}$ to September $12^{\text {th }}, 2013$.

Tab. 2. Abundances and structural metrics (i.e., number of taxa and Shannon-Wiener index) of the aquatic communities at the two study sites of the Ticino River (S1 and S2). Data were collected among 2010 and 2014 for benthic macroinvertebrates, and from 2010 to 2012 for the other ecological groups. Average values ( \pm standard deviation) are reported for the entire study period (total), for August and September samplings (i.e., summer) and for the other seasons. No data about "other seasons" are shown for macrophytes, which were always collected during summer. Data about fish communities are available only as the sum of multiple observations.

\begin{tabular}{|c|c|c|c|c|c|c|}
\hline & \multicolumn{3}{|c|}{ S1 } & \multicolumn{3}{|c|}{ S2 } \\
\hline & Total & Summer & Other seasons & Total & Summer & Other seasons \\
\hline \multicolumn{7}{|l|}{ Diatoms } \\
\hline $\mathrm{n}^{\circ}$ of species & $32 \pm 5$ & $33 \pm 7$ & $30 \pm 2$ & $30 \pm 8$ & $35 \pm 8$ & $24 \pm 5$ \\
\hline Shannon-Wiener index & $3.33 \pm 0.43$ & $3.01 \pm 0.27$ & $3.66 \pm 0.29$ & $3.01 \pm 0.77$ & $3.19 \pm 0.14$ & $2.82 \pm 1.17$ \\
\hline \multicolumn{7}{|l|}{ Macrophytes } \\
\hline $\mathrm{n}^{\circ}$ of species & - & $19 \pm 2$ & - & - & $23 \pm 5$ & - \\
\hline Cover $(\%)$ & - & $42 \pm 32$ & - & - & $55 \pm 49$ & - \\
\hline \multicolumn{7}{|l|}{ Macroinvertebrates } \\
\hline $\mathrm{n}^{\circ}$ of families & $24 \pm 5$ & $24 \pm 5$ & $25 \pm 6$ & $26 \pm 5$ & $29 \pm 4$ & $25 \pm 6$ \\
\hline Total density (individuals $\mathrm{m}^{-2}$ ) & $3427 \pm 3952$ & $2700 \pm 2341$ & $3790 \pm 4579$ & $1884 \pm 1292$ & $1625 \pm 1265$ & $2046 \pm 1350$ \\
\hline Shannon-Wiener index & $1.66 \pm 0.31$ & $1.59 \pm 0.26$ & $1.69 \pm 0.34$ & $2.00 \pm 0.29$ & $2.03 \pm 0.27$ & $1.96 \pm 0.29$ \\
\hline \multicolumn{7}{|l|}{ Fish } \\
\hline $\mathrm{n}^{\circ}$ of species & 19 & - & - & 23 & - & - \\
\hline $\mathrm{n}^{\circ}$ of autochthonous species & 15 & - & - & 16 & - & - \\
\hline $\mathrm{n}^{\circ}$ of allochthonous species & 4 & - & - & 7 & - & - \\
\hline
\end{tabular}


ture. In these low-flow periods, extreme water temperatures were measured as well, with minimum values in February and maximum values in August. During winter, the discharge variation was lower than in summer, as a consequence low temperature events lasted longer than high temperature events, which, on the contrary, were more frequent. Therefore, 1-, 7- and 30-day minima were more similar to each other than 1-, 7- and 30day maxima. During summer, the presence of local hydro-morphological features such as river/groundwater interaction and seeps appeared to have a buffer action, at least locally. The increase in flow values between S1 and S2 during the low-flow periods is mainly ascribed to the groundwater contribution as mentioned above. During these periods, groundwater accounted for approximately $10-20 \%$ of the river discharge at S2 (with maximum values in August) and the river temperature remained relatively low in spite of the high air temperature. This buffer action was not observed when the discharge released from the lake increased. Moreover, at S2, water temperature considerably decreased in correspondence of a seep. On the contrary, in shallow water, the temperature increased laterally (by $3.4^{\circ} \mathrm{C}$ within 5 $\mathrm{m})$ as an effect of the air/water exchange. Thus, the riverbed morphology and the consequent air/water and river/groundwater interactions appeared to be important determinants of the lateral variation in water temperature, generating a patchy thermal habitat. The conservation of a locally-heterogeneous physical environment guarantees patches of cool water during summer lowflows. The importance of hydro-morphological heterogeneity for temperature variability and for supporting thermal refugia has already been highlighted by many Authors (Gostner et al., 2011; Arscott et al., 2001). For instance, Arscott et al. (2001) found strong lateral variations in water temperature, which, in lowland braided contexts, can equal those measured longitudinally along the entire watercourse.

Although temporal and lateral variations were evident, temperatures recorded monthly were comparable among the three sampling sites (i.e., the Miorina Dam, S1 and $\mathrm{S} 2$ ), suggesting a scarce longitudinal variation in the 30$\mathrm{km}$ study reach. However, since at S1 and S2 water withdrawal caused longer periods of low flows, an exacerbation of the duration of extreme temperature events can be expected. Temperature data collected with daily frequency, whether also available for these sections, could allow the confirmation of this hypothesis.

Finally, important depth variation was not detected at S2 during low-flow conditions and was negligible for the majority of the study reach downstream of the water diversions, since in this stretch run and riffle areas are predominant with respect to deep waters (i.e., pools). The absence of vertical variations in water temperature makes the lateral temperature variations and the maintenance of a heterogeneous morphology even more important.

\section{Possible effects of thermal alteration on aquatic communities}

Each aquatic species has a thermal preference and is characterized by a tolerance range of water temperatures depending on its adaptive capability through physiological adjustments or behavioural thermoregulation (Barko et al., 1986; Buisson et al., 2008; Souffreau et al., 2010; Dallas and Rivers-Moore, 2012). The degree of thermal stress outside the tolerance zone is also a function of the exposure time and the rate at which the temperature changes (Beitinger et al., 2000; Dallas and Rivers-Moore, 2012). However, upper thermal limits provide insight into the relative sensitivity of species to high temperatures and are likely to be of the greatest ecological significance in river systems exposed to severe water stress and relatively high temperatures, such as the Ticino River. Indeed, for those species having pronounced thermal requirements, temperature is one of the main determinant factors of spatial distribution (De Nicola, 1996; Buisson et al., 2008; Jonsson and Jonsson, 2009). As a consequence, temperature effects on single species potentially affect the community composition.

The aquatic communities recorded at the two study sites (i.e., $\mathrm{S} 1$ and $\mathrm{S} 2$ ) of the Ticino River were similar except for the higher diversity of benthic macroinvertebrates at S2 than at S1, probably due to slight differences in substrate composition. Even the differences between samples collected in summer and those collected during the other seasons for the benthic communities (i.e., diatoms and macroinvertebrates) were not significant. Upper limits of the resistance range and thermal preferences of the main taxonomical groups recorded at both sites are compared and discussed below.

The maximum temperature recorded during the warmest month of the year (i.e., August) in 2013 in the study area $\left(\right.$ i.e., $\left.27^{\circ} \mathrm{C}\right)$ is lower than the upper thermal limit (i.e., $30^{\circ} \mathrm{C}$ ) above which species diversity, biomass and maximum areal productivity of lotic periphyton decrease (De Nicola, 1996) and is within the thermal preference of most benthic diatoms living in temperate zones (Patrick, 1977). However, although many species of diatoms are eurythermic, some species recorded in the Ticino River, e.g., Achnanthes sp. $\left(<14^{\circ} \mathrm{C}\right)$ and Navicula sp. (ca. $8-12^{\circ} \mathrm{C}$ ), prefer cool water, whereas other species, e.g., Cocconeis $\left(>25^{\circ} \mathrm{C}\right)$ and Nitzschia $\left(22-39^{\circ} \mathrm{C}\right)$, prefer warm water (De Nicola, 1996).

Similar considerations can be made for many submersed macrophytes for which the upper thermal optimum is in the range of $28-32^{\circ} \mathrm{C}$ (Barko et al., 1986). Thus, summer temperatures in the Ticino River are not expected to limit the growth of primary producers. On the contrary, summer temperature could favour the biomass growth of 
primary producers, as well as that of their consumers (Friedberg et al., 2009), potentially modifying fluvial metabolism.

According to Dallas and Rivers-Moore (2012), the most thermally sensitive families of benthic macroinvertebrates belong to the insect orders of Plecoptera, Trichoptera and Ephemeroptera. However, among these, the reported experimental upper thermal limits for the most sensitive families found in the Ticino River (e.g., Baetidae, Heptageniidae, Hydropsychidae, Leptoceridae, and Philopotamidae) are above $30^{\circ} \mathrm{C}$ (Dallas and Rivers-Moore, 2012), thus excluding possible direct effects of the summer temperatures on these taxa.

Concerning fish, in the Ticino River both warm-water (such as common - Cyprinus carpio - and crucian - Carassius carassius - carps, and tench - Tinca tinca), cool-water (such as pike - Esox lucius - and pumpkinseed - Lepomis gibbosus) and cold-water (such as rainbow trout - Onchorhynchus mykiss - and Atlantic trout - Salmo trutta) species are present (Eaton and Scheller, 1996; Buisson et al., 2008). Between these species, the Italian spined loach and the Italian riffle dace are among the most abundant autochthonous species with a relatively low upper limit of resistance: $25^{\circ} \mathrm{C}$ (Leuven et al., 2011) and $27^{\circ} \mathrm{C}$ (Souchon and Tissot, 2012), respectively. On the contrary, the most abundant alien invasive species such as bitterling or European catfish have higher limits: $37^{\circ} \mathrm{C}$ and $32^{\circ} \mathrm{C}$, respectively (Souchon and Tissot, 2012). Moreover, almost all of the alien species recorded in the study reach have an upper limit equal to or above $30^{\circ} \mathrm{C}$ (Leuven et al., 2011; Souchon and Tissot, 2012). This fact, along with the wider range of temperatures preferred by the alien species compared with the autochthonous species, could result in a competitive disadvantage for the latter, thus expressing alien species potential of altering instream community structure (Strayer, 2010). Species such as the European catfish and the pumpkinseed might expand their invading range favoured by elevated temperatures under predicted future climate scenarios (Britton et al., 2010; Agdamar et al., 2015). However, fish species with lower thermal tolerance may thermoregulate behaviourally by migrating to more suitable thermal habitats, such as the cool-water seep observed in the monitored Ticino reach.

The timing of spawning varies among and within species with temperature fluctuations which might or not be beneficial for the offspring in terms of habitat availability, growth period, food competition and finally fitness and survival (Gillet and Quetin, 2006). Temperature and related oxygen supply are indeed considered as main factors determining the duration of the embryonic period, embryonic mortality as well as growth and conditions of newly hatched larvae (Schiemer et al., 2002). Most of the species in the Ticino River spawn in spring and summer, thus alevin and fry can be exposed to high summer temperatures.

\section{Management considerations}

Natural flow is one of the main determinants of fluvial ecosystem integrity (Poff et al., 1997), influencing both ecosystem structure and function. However, to date, in the study reach as well as in most of the Italian watercourses, MF is the only component of e-flows which is undergoing implementation. A careful choice of the entity of MF values is thus particularly important to prevent negative effects on both ecosystem structure and function.

In the Ticino River, the summer MF value (i.e., $12 \mathrm{~m}^{3}$ $\mathrm{s}^{-1}$ at the Panperduto Dam) could guarantee acceptable thermal characteristics in reaches where a heterogeneous morphological structure was present and river-groundwater interaction occurred. However, a detailed study on the differences in water temperature among days with different MF values could give additional information about the acceptability of specific MFs. For example, from a preliminary data collection (Ticino Consortium, 2013), the difference between air maximum temperature and water maximum temperature was greater in days with MF equal to $28 \mathrm{~m}^{3} \mathrm{~s}^{-1}$ (i.e., $7^{\circ} \mathrm{C}$ ) than in days with $\mathrm{MF}$ equal to $12 \mathrm{~m}^{3}$ $\mathrm{s}^{-1}\left(\right.$ i.e., $\left.5^{\circ} \mathrm{C}\right)$, considering couples of consecutive days with comparable meteorological conditions. These data suggest that higher MF values could mitigate maximum water temperature increase caused by air/water thermal exchange, limiting the summer water temperature increase and contributing to a reduction of the potential negative effects on aquatic communities discussed in the previous section.

The definition of such MFs should take into account the expected future climate changes. As an example, a further decrease of summer flows is expected as a consequence of the anticipation of high flows to early spring (Barnett et al., 2005).

Another important aspect associated to flow management is the occurrence of sharp flow variation events, such as that recorded at $\mathrm{S} 2$ after a period of abundant rainfall. In this case, an increase of approximately $4^{\circ} \mathrm{C}$ within $5 \mathrm{~h}$ was recorded when the flow increased from the MF value up to $>300 \mathrm{~m}^{3} \mathrm{~s}^{-1}$. While in the upper Ticino River hydro-power production determines both hydropeaking and thermopeaking downstream of the reservoirs (Frutiger et al., 2004), the flow regulation of the lowland course is not characterized by these phenomena. However, this issue should be better investigated since the effects on aquatic communities could be not negligible (Carolli et al., 2012; Bruno et al., 2013).

\section{CONCLUSIONS}

In the Ticino River temporal variations in water temperature were mainly detected as an effect of flow management.

Since water is released into the Ticino River from the 
surface of the lake, during summer the more water is released, the higher the minimum temperatures within the study reach are. On the other hand, maximum temperatures in the river are reached in shallow waters as an effect of air/water interaction. Thus, in the case of low flows, river temperature along a section ranges among a maximum that is higher than the temperature at the lake outlet, due to shallow water warming, and a minimum that is lower than the temperature at the lake outlet, due to the groundwater contribution. Where this contribution is present, the streambed/water exchange produces indeed lateral variations in temperature and guarantees patches of cool water even during the warmest month.

The measured temperature patterns in the Ticino River lye within the thermal limits of most of the aquatic taxa collected in the study area. However, effects on instream community structure and on river metabolism are supposed to increase with the expected future climate changes (i.e., increase in summer temperatures and decrease in low-flow values).

Since our results show that a heterogeneous river morphology could help in the prevention of extreme temperature conditions during summer, further studies should be carried out in the study area to investigate river reaches with a poor morphology. Moreover, further analysis should be performed during the low-flow winter period to investigate possible ecological effects of temperature minima. Both these insights could improve the knowledge on flow-temperature relationships in highly regulated lowland rivers and could contribute to the definition of adequate e-flows.

\section{ACKNOWLEDGMENTS}

This study was partially funded by the Ticino Consortium as part of the project "Minimum flow trial in the lowland Ticino River" (Sperimentazione del deflusso minimo vitale sul fiume Ticino sublacuale). We especially thank Valentina Soldati for the field work.

\section{REFERENCES}

Ağdamar S, Tarkan AS, Keskin E, Top N, Doğaç E, Baysal Ö, Emiroğlu Ö. 2015. The role of environmental factors and genetic diversity on colonization success of a non-native fish, Lepomis gibbosus from western part of Turkey. Biochem. Syst. Ecol. 58:195-203.

Ambrosetti W, Barbanti L, Rolla A, 2006. The climate of Lago Maggiore area during the last fifty years. J. Limnol. 65 (Suppl. 1):1-62.

Arscott DB, Tockner K, Ward JV, 2001. Thermal heterogeneity along a braided floodplain river (Tagliamento River, northeastern Italy). Can. J. Fish. Aquat. Sci. 58:2359-2373.

Barko JW, Adams MS, Clesceri NL, 1986. Environmental factors and their consideration in the management of submersed aquatic vegetation: a review. J. Aquat. Plant Manage. 24:1-10.

Barnett TP, Adam JC, Lettenmaier DP, 2005. Potential impacts of a warming climate on water availability in snow-dominated regions. Nature. 438:303-309.

Beitinger TL, Bennett WA, McCauley RW, 2000. Temperature tolerances of North American freshwater fishes exposed to dynamic changes in temperature. Environ. Biol. Fish. 58:237-275.

Britton JR, Cucherousset J, Davies GD, Godard MJ, Copp GH, 2010. Non-native fishes and climate change: predicting species responses to warming temperatures in a temperate region. Freshwater Biol. 55:1130-1141.

Brown LE, Hannah DM, 2008. Spatial heterogeneity of water temperature across an alpine river basin. Hydrol. Process. 22:954-967.

Bruno MC, Siviglia A, Carolli M, Maiolini B, 2013. Multiple drift responses of benthic invertebrates to interacting hydropeaking and thermopeaking waves. Ecohydrology 6:511-622.

Buisson L, Blanc L, Grenouillet G, 2008. Modelling stream fish species distribution in a river network: the relative effects of temperature versus physical factors. Ecol. Freshw. Fish. 17:244-257.

Bunn SE, Arthington AH, 2002. Basic principles and ecological consequences of altered flow regimes for aquatic biodiversity. Environ. Manage. 30:492-507.

Caissie D, 2006. The thermal regime of rivers: a review. Freshwater Biol. 51:1389-1406.

Carolli M, Bruno MC, Siviglia A, Maiolini B, 2012. Responses of benthic invertebrates to abrupt changes of temperature in flume simulations. River Res. Appl. 280:678-691.

Casas-Mulet R, Alfredsen K, Hamududu B, Timalsina NP, 2015. The effects of hydropeaking on hyporheic interactions based on field experiments. Hydrol. Process. 29:1370-1384.

Colwell RK, 1974. Predictability, constancy, and contingency of periodic phenomena. Ecology 55:1148-1153.

Dallas HF, Rivers-Moore NA, 2012. Critical thermal maxima of aquatic macroinvertebrates: towards identifying bioindicators of thermal alteration. Hydrobiologia. 679:61-76.

De Nicola DM, 1996. Periphyton responses to temperature at different ecological levels, p. 150-175. In: R.J. Stevenson, M.L. Bothwell, R.L. Lowe and J.H. Thorp (eds.), Algal ecology: freshwater benthic ecosystem. Academic Press.

Dokulil M, 2013. Impact of climate warming on European inland waters. Inland Waters 4:27-40.

Eaton JG, Scheller RM, 1996. Effects of climate warming on fish thermal habitat in streams of the United States. Limnol. Oceanogr. 41:1109-1115.

Friberg N, Dybkjaer JB, Olafsson JS, Gislason GM, Larsen SE, Lauridsen TL, 2009. Relationships between structure and function in streams contrasting in temperature. Freshwater Biol. 54:2051-2068.

Frutiger A, 2004. Ecological impacts of hydroelectric power production on the River Ticino. Part 1: Thermal effects. Arch. Hydrobiol. 159:43-56.

Gerecht KE, Bayani Cardenas M, Guswa AJ, Sawyer AH, Nowinski JD, Swanson TE, 2011. Dynamics of hyporheic flow and heat transport across a bed-to-bank continuum in a large regulated river. Water Resour. Res. 47:W03524.

Gillet C, Quetin P, 2006. Effect of temperature changes on the reproductive cycle of roach in Lake Geneva from 1983 to 2001. J. Fish Biol. 69:518-534.

Gostner W, Peter A, Schleiss AJ, 2011. Temperature regime in a 
braided river system: an indicator for morphological heterogeneity and ecological potential. Proceedings of the $34^{\text {th }}$ World Congress of the International Association for Hydro- Environment Research and Engineering: 33 $3^{\text {rd }}$ Hydrology and Water Resources Symposium and $10^{\text {th }}$ Conference on Hydraulics in Water Engineering. Barton, A.C.T., Engineers, Australia.

Hari RE, Livingstone DM, Siber R, Burkhardt-Holm P, Guttinger H, 2006. Consequences of climatic change for water temperature and brown trout populations in alpine rivers and streams. Glob. Chang. Biol. 120:10-26.

Haxton TJ, Findlay CS, 2008. Meta-analysis of the impacts of water management on aquatic communities. Can. J. Fish. Aquat. Sci. 65:437-447.

Isaak DJ, Wollrab S, Horan D, Chandler G, 2012. Climate change effects on stream and river temperatures across the northwest US from 1980-2009 and implications for salmonid fishes. Clim. Chang. 113:499-524.

Jonsson B, Jonsson N, 2009. A review of the likely effects of climate change on anadromous Atlantic salmon Salmo salar and brown trout Salmo trutta, with particular reference to water temperature and flow. J. Fish Biol. 75:2381-2447.

Leuven RSEW, Hendriks AJ, Huijbregts MAJ, Lenders HJR, Matthews J, Van der Velde G, 2011. Differences in sensitivity of native and exotic fish species to changes in river temperature. Curr. Zool. 57:852-862.

Lowney CL, 2000. Stream temperature variation in regulated rivers: Evidence for a spatial pattern in daily minimum and maximum magnitudes. Water Resour. Res. 36:2947-2955.

Mantua N, Tohver I, Hamlet A, 2010. Climate change impacts on streamflow extremes and summertime stream temperature and their possible consequences for freshwater salmon habitat in Washington State. Clim. Chang. 102:187-223.

Naiman RJ, Latterell JJ, Pettit NE, Olden JD, 2008. Flow variability and the biophysical vitality of river systems. C.R. Geosci. 340:629-643.

Olden JD, Naiman RJ, 2010. Incorporating thermal regimes into environmental flows assessments: modifying dam operations to restore freshwater ecosystem integrity. Freshwater Biol. 55:86-107.

Orr HG, Simpson GL, des Clers S, Watts G, Hughes M, Hannaford J, Dunbar MJ, Laizé CLR, Wilby RL, Battarbee RW, and Evans R, 2015. Detecting changing river temperatures in England and Wales. Hydrol. Process. 29:752-766.

Patrick R, 1977. Ecology of freshwater diatoms and diatom communities, p. 297-299. In: D. Werner (ed.) The biology of diatoms, 13. University of California Press.

Poff NL, Allan JD, Bain MB, Karr JR, Prestegaard KL, Richter BD, Sparks RE, Stromberg JC, 1997. The natural flow regime. BioScience. 47:769-784.

Poff NL, Richter BD, Arthington AH, Bunn SE, Naiman RJ, Kendy E, Acreman M, Apse C, Bledsoe BP, Freeman MC, Henriksen J, Jacobson RB, Kennen G, Merritt DM, O'Keeffe JH, Olden JD, Rogers K, Tharme RE, Warner A, 2010.
The ecological limits of hydrologic alteration (ELOHA): a new framework for developing regional environmental flow standards. Freshwater Biol. 55:147-170.

Poff NL, Zimmerman JK, 2010. Ecological responses to altered flow regimes: a literature review to inform the science and management of environmental flows. Freshwater Biol. 55:194-205.

Poole GC, Berman CH, 2001. An ecological perspective on instream temperature: natural heat dynamics and mechanisms of human-caused thermal degradation. Environ. Manage. 27:787-802.

Schiemer F, Keckeis H, Kamler E, 2002. The early life history stages of riverine fish: ecophysiological and environmental bottlenecks. Comp. Biochem. Phys. A. 133:439-449.

Schneider C, Laizé CLR, Acreman MC, Florke M, 2013. How will climate change modify river flow regimes in Europe? Hydrol. Earth Syst. Sci. 17:325-339.

Smith K, 1981. The prediction of river water temperatures/prédiction des températures des eaux de rivière. Hydrolog. Sci. J. 26:19-32.

Souffreau C, Vanormelingen P, Verleyen E, Sabbe K, Vyverman $\mathrm{W}, 2010$. Tolerance of benthic diatoms from temperate aquatic and terrestrial habitats to experimental desiccation and temperature stress. Phycologia 49:309-324.

Souchon Y, Tissot L, 2012. Synthesis of thermal tolerances of the common freshwater fish species in large Western Europe rivers. Knowl. Manag. Aquat. Ec. 405:1-48.

Strayer DL, 2010. Alien species in fresh waters: ecological effects, interactions with other stressors, and prospects for the future. Freshwater Biol. 55:152-174.

Ticino Consortium, 2013. [Sperimentazione del deflusso minimo vitale sul fiume Ticino sublacuale - Monitoraggio ecologico. Rapporto finale 2010-2012].[In Italian]. Available from: www.ticinoconsorzio.it

Toffolon M, Siviglia A, Zolezzi G, 2010. Thermal wave dynamics in rivers affected by hydropeaking. Water Resour. Res. 46:W08536.

van Vliet MT, Franssen WH, Yearsley JR, Ludwig F, Haddeland I, Lettenmaier DP, Kabat P, 2013. Global river discharge and water temperature under climate change. Glob. Environ. Chang. 23:450-464.

Vanzo D, Siviglia A, Carolli M, Zolezzi G, 2016. Characterization of sub-daily thermal regime in alpine rivers: quantification of alterations induced by hydropeaking. Hydrol. Process. 30:1052-1070.

Ward JV, 1985. Thermal characteristics of running waters. Hydrobiologia 125:31-46.

Webb BW, Hannah DM, Moore RD, Brown LE, Nobilis F, 2008. Recent advances in stream and river temperature research. Hydrol. Process. 22:902-918.

Zolezzi G, Siviglia A, Toffolon M, Maiolini B, 2011. Thermopeaking in Alpine streams: event characterization and time scales. Ecohydrology 4:564-576. 